\title{
Study Abroad and the City: Bringing the Lessons Home
}

\section{Elizabeth Brewer}

Beloit College

On a warm, June afternoon in 2005 , faculty members set out in teams of three or four to explore the city of Beloit, WI, population c. 35,000. Half the teams head to a neighborhood on Beloit's west side, a part of town largely unknown to them. Arriving by car, they park in different locations and set off on foot to explore and to record information about the neighborhood's infrastructure, housing, residents, and ambience. Equipped with digital cameras, each team will also take photos from which they will later select a key few to make a presentation on what they now know about the neighborhood, and the questions their explorations have raised. Later, they will visit the more familiar downtown, trading places with the teams that, having recorded their explorations of this area, will now head to the neighborhood the others have left.

Kevin Lynch (1960), based on a 5-year study of how people organize spatial information as they navigate cities, found five concepts at work landmarks, paths, districts, nodes, and edges — in people's decision-making about their travel from one place to another. Landmarks tend to operate as guideposts, while paths are the routes people use to travel from one place to another. Districts can be recognized by location and image (Beloit's downtown), whereas nodes are characterized by the large number of people who pass through them (in larger cities, bus and train stations might serve as nodes, in Beloit, major intersections or the summer farmers market). Edges, natural or artificial, act as barriers or passageways.

Earlier in the day, the faculty members each had drawn a mental map of Beloit. Denser maps, illustrated with landmarks (houses, a grocery store, the public library) and crossed by idiosyncratic paths (the smaller roads used to travel from home to work, visit friends, stroll or bike), tended to be made by those among the group who actually live in Beloit, and not just travel there for work. Empty spaces and a lack of detail characterized other maps, whose dominant features tended to be the paths (highways and main roads) that guided their authors to and from the campus and the edges (river, highway) 
that helped determine which parts of the city they traveled in. Beloit's west side was largely missing from the mental maps, located as it was on the other side of the Rock River, an edge that acts as a barrier for many at Beloit College, because the College and residential areas most that faculty live in are located east of the river. In common with all the maps was one district, the historical section of Beloit, at one end of which sits Beloit College. As well, whether more densely drawn or less, the mental maps, when compared with actual maps, showed the subjectivity of the mental maps' scale and content and how little of the city was actually depicted. The purpose of the explorations on foot, then, was to begin to get to know both the seemingly familiar (downtown)and unfamiliar (Beloit's west side) as they actually are, and in follow up discussions, reflect on what this might tell the group about the challenges study abroad students face upon arriving in their host sites, which very often are cities. The next step would be to design assignments for students to investigate their study abroad cities.

\section{The Challenges of Becoming Acquainted}

Study abroad's purpose, once conceived primarily as a means for acquiring knowledge in a content area as well as language acquisition, began in the 1980s to be considered a vehicle for helping American students become less "parochial" (Bok, 1986, p. 170) and better prepared to live and work in a globalized world. To achieve these goals, students must be able to acquire content knowledge (Kulacki, 2000; Pusch \& Merrill, 2008), develop interculturally (Deardorff, 2008; Vande Berg, 2007), and learn experientially (Bennett, 2008; Pusch \& Merrill, 2008; Selby, 2008). As well, consistent with the reflection stage in the experiential learning cycle, they need to be able to communicate (verbally, non-verbally) in country, and express what they have learned both during and after the study abroad experience. While the number of Americans studying foreign languages has continued to decrease (American Council on Education, 2008), language acquisition remains central to some study abroad programs and the missions of some U.S. colleges and universities. Placement in a foreign language environment is not sufficient to advance students' language skills, however, as evidenced by research conducted by the Georgetown Consortium Project (Vande Berg, Paige, \& Connor-Linton, 2009); instead students must actively use the target language outside the classroom on a regular basis. Indeed, findings from the Georgetown Consortium Project suggest that intercultural 
development will also be advanced if interventions are provided on-site and throughout the study abroad sojourn. Such interventions include opportunities for group reflection and engagement with host communities.

Jane Edwards (2000) has argued that study abroad students need to be taught ethnographic and participant observation skills if they are to investigate and make sense of the new environments in which they find themselves. Scott Blair, writing elsewhere in this volume on "Study Abroad and the City: Mapping Urban Identity," argues that they also be taught mapping skills in order to locate both visible and invisible parts of the city. Darren Kelly's work (2010 a.) with study abroad students in Dublin and other countries has combined the two approaches to enable students to move beyond the main thoroughfares and nodes that tend to delimit the territories they normally travel. As he discusses, a variety of factors prevent students from exploring the cities in which they find themselves abroad, from cafes and restaurants that beckon because they seem familiar and safe, in part because other foreigners gather in them, to fears of getting lost or being uncomfortable in strange surroundings. It can also be easier and more comfortable to rely on technology for instant communication and companionship with friends and family members located half-way around the world, rather than do the hard work of trying to communicate with local people, who after all, both strangers and people who speak and act differently from them. It does not matter that it was these very strangers that the students had thought they wanted to get to know when they first conceived of going abroad. Indeed, research Kelly (2010 b.) conducted with students in Ireland on their use of electronic technology during study abroad helped them realize how many opportunities they had missed to actually be in Ireland because they were spending so much time in cyberspace.

A significant percentage of Beloit College students who study abroad do so by enrolling directly in a university abroad. In the 1980s, the College had begun moving away from faculty-led programs to exchanges and direct enrollment, in part because faculty were increasingly unavailable for semester long sojourns abroad, the standard length for study abroad at the College. As well, as the number of students studying abroad increased, the College simply did not have sufficient numbers of faculty members to both accompany students abroad and teach the curriculum at home. The college is small, although at roughly 1,250 students in 2010, it is larger than it was 30 years ago. With 100 faculty members, however, some academic programs have only one, two, or 
three full-time faculty devoted to them. The cost advantage of exchanges and direct enrollment to the institution and its students aside, exchanges and direct enrollment also make it possible for students in all disciplines to study abroad, and take courses in their major or minor when doing so. An additional benefit of exchanges is the opportunity to bring student from partner universities to Beloit College for one or two semesters. While the College does not look to international students alone as a vehicle for internationalizing the curriculum and campus, international students do bring new perspectives to classroom discussions. As a recent graduate reported, "my senior seminar was so interesting because the students came from so many countries or had studied abroad, and their capstone projects reflected this. I learned so much about the world and how economics plays out in different countries" ( $\mathrm{J}$. Fu, personal communication, August 5, 2010). In another vein, a student reported that his decision to study abroad was influenced by the presence of so many exchange students on campus, while faculty routinely hope that exchange students will enroll in their courses because of the perspectives they will bring to class discussions.

Despite these stated benefit of exchanges and direct enrollment, however, faculty were conscious of the fact that students were not always returning to Beloit from study abroad with the knowledge the faculty members had hoped they would acquire. This was particularly easy to see when language and culture were the focus of study, yet a semester spent in the target country did not strengthen students' knowledge of these to a significant degree. Although advocates of international exchanges have argued that these provide the best learning environment for study abroad students because they immerse students in local universities (Carlson, Burn, Useem, and Yachimowicz, 1990), the experience at Beloit College indicated that placement in a university abroad in itself would not necessarily advance students' learning. There are a variety of reasons for this, but among them are differences in educational traditions and practices as well as resources questions. Many U.S. students, including Beloit College students, are accustomed to learner-centered teaching with regular, graded assignments and considerable guidance from faculty members. When confronted with the absence of these at their host universities, as well as a pedagogy more centered on the delivery of knowledge rather than students acquiring that knowledge, students educated in the U.S. tend not to know how to push themselves to make advances in language learning nor how to engage in meaningful ways with the local environment and local residents. As one Beloit student reported of her 
experience taking classes in a university abroad, “. . . your professors will not baby you. If you miss and assignment, there will be no email wondering where it is. You are expected to learn by yourself" (Beloit College a., 2009-2010). Indeed, an analysis of study abroad evaluations indicates that while the type of program does not play a role in students' overall satisfaction with their study abroad experience, students who enroll directly in a university abroad are less likely to find strong connection to their major than students who enroll in provider programs (Beloit College, 2010).

Rebecca Solnit has written about the value of getting lost intelligently in order to discover: "[When] you get lost, the world has become larger than your knowledge of it" (2005, p. 22). Getting lost means giving up some control, but if one knows how to get lost intelligently, it also leads to learning and growth. Indeed, if we never get lost, our world remains very narrow. The task for Beloit College faculty was thus to discover ways to teach students how to get lost intelligently while abroad, so that they could become advance their learning. In essence, the challenge was to facilitate the interventions that have advanced learning in some study abroad programs (opportunities for engagement outside the classroom, group reflections on cultural experiences, and so on) while maintaining its exchange programs and avoiding assigning a faculty member full-time to the study abroad site. The vehicle for these at two of the College's exchange partner sites would be distance learning courses taught by faculty located in Beloit, with assignments carried out by the students on-site, and conveyed back to Beloit via the internet. Both of these courses, as well as others created or modified in a series of faculty development activities, would use the cities in which the students were located as laboratories for learning.

\section{The Need for Faculty Development}

A major study of faculty development in higher education (Sorcinelli, M.D., Austin, A.E., Eddy, P.L., and Beach, A.L. 2006), discussed by one of its authors Mary Deane Sorcinelli (2007) in an essay for the Association of American Colleges and Universities' peerReview, identifies three primary challenges for faculty development in the U.S. Of particular relevance to this article is "the changing nature of teaching, learning, and scholarship" (p. 4), felt by respondents to the study's survey to be "the most important issue to address through faculty development services and activities" (p. 6). At issue is the need for faculty to move from lecturing as the primary teaching 
tool to learner-centered teaching requiring a different set of teaching skills, including the ability to create opportunities for active learning. Examples of such opportunities that might be explored in faculty development activities include "student-led discussions, team learning, peer learning, oral presentations, writing-to-learn activities, case studies, and study groups" (p. 7). These kinds of active learning strategies are in wide and regular use in many classes on U.S. campuses, including at Beloit College. However, many of these assume that the activities will take place in the classroom, something that would not be the case with the distance learning courses Beloit College hoped to create for students at selected partner universities.

Michael Stohl (2007) has argued that the transformational learning promised by internationalization can only take place if faculty members are prepared to teach for it. Madeleine Green and Christa Olsen (2003) similarly have argued that faculty development is essential to internationalization efforts. Further, they note that to be effective, faculty development must have "faculty ownership, choice, and support," be integrated with "other internationalization strategies," and be extended to an ever-expanding "circle of engaged faculty" (Green and Olsen, 2003, p. 78). Ultimately, this is the kind of outcome that would emerge at Beloit College through faculty development around the city and study abroad. First, however, the challenge for faculty members would be to adapt their teaching to study abroad, in which context much of what would attract their students' attention would lie outside the classroom. The ideal, or course, is to find ways to create a dialogue between what happens inside the classroom and the experiences outside the classroom.

What were the challenges for the faculty members concerned about what their students were learning in the semesters they were spending at exchange partner universities? Those most closely aligned with exchange partners in China and Russia, for example, had studied language and literature and these were the focus of most of their teaching on campus. Texts discussed in the classroom, not experiential learning undertaken in the city, were the main basis for their teaching. Many of the students who studied in China and Russia, however, were not majoring in language and literature, and even if they were, frequently had a second major in another discipline. As well, although all were liberal arts students, studying multiple subjects and developing the capacity to connect these, they were not necessarily yet sophisticated or experienced enough to draw on their other studies to understand, for example, that the portable toilets 
dotting the streets of Moscow represent an advance in public health, or that the seemingly loose structure of the night market in Kaifeng is actually undergirded by a cooperative network of economic borrowing and trading amongst the various vendors. To help students make these connections, the faculty would need to become less disciplinary and more interdisciplinary, and build confidence in developing experiential learning assignments. As well, as they engaged in faculty development activities and began teaching the new courses, they would become more conscious of the importance of the affective domain in hindering or fostering learning in study abroad.

\section{Faculty Development around the City and Study Abroad: The Cities in Transition Project}

Beloit College has sought to involve faculty in study abroad since its formal establishment at the College in 1960. For a number of years, faculty development around study abroad at Beloit College consisted of membership in oversight and selection committees, visits to study abroad sites, the occasional faculty member accompanying students to a study abroad site to serve as an advisor, and participation in faculty development seminars offered by study abroad providers. Early in the current century, however, faculty began convening in ad-hoc groups with the director of international education to discuss ways to strengthen study abroad learning outcomes.

Beloit felt it was inappropriate to expect partner universities to devote resources and change their educational philosophy and practice to meet the educational norms to which Beloit students had been acculturated. However, the College could enlist these universities' support to allow it to experiment with ways to give its students greater agency when studying at them. This led to a second initiative, namely to strengthen the study abroad experience at partner universities through curricular innovations involving study of the city. Interested faculty members applied to a Beloit College innovation fund for support for a curriculum development workshop around the theme of Cities in Transition. The workshop theme had emerged partly by design and partly by coincidence: a number of faculty members had been exploring the theme of urban environments in transition. The ESL instructor and international education director, for example, had refocused an orientation seminar for exchange students around the city of Beloit 
to help students begin to understand the city in which they would study and live for the coming semester or year. A course taught both on-site and remotely for students studying in Shanghai had been created with funding from the Freeman Foundation; the city of Shanghai served as the arena for advancing language skills and students' understanding of China. As well, a faculty development seminar based in Shanghai with an extended excursion to Anhui Province had brought together an interdisciplinary group of faculty interested in connecting their teaching and research to China. Others had visited Beloit College's partners in Ecuador and Senegal with the same intentions. Participants in these visits subsequently incorporated the target countries into their teaching, whether in language and culture courses, gender and women's studies, medical anthropology, interdisciplinary courses, or first year seminars. Discussions also had been held about offering a course in Quito to engage students with the city in an intentional way. The Cities in Transition workshop would draw on these separate activities to bring faculty members together to "1) establish a set of learning goals around the city; 2) discuss both the advantages and limitations of various program models; 3 ) exchange practical experience on how best to conduct such programs; 4) establish a roadmap for how to continue forward" (Beloit College, 2004).

Why cities in transition? On a practical level, the factor most clearly connecting the faculty members' different interests was the fact that students' learning was taking place in the cities in which exchange partners were located. However, more conceptually, complex urban locations seemed ideal for encouraging students to adopt cross-disciplinary perspectives on great historical and cultural forces, the effects of globalization, the human impact on the environment, and social issues. They also offered myriad opportunities for students to investigate these and the various transitions taking place outside university walls. Workshop participants would explore a variety of formats - semester long courses, intensive orientation seminars, distance learning opportunities — and approaches to experiential education — field research, service learning, volunteering, internships - that promised to enable Beloit students to apply their liberal arts education in meaningful and innovative ways, whether in residence at the College or studying abroad. The role of language development and observation would be a focus, and room would be allowed in the workshop for the initial development of specific exercises, assignments, and syllabi.

Ultimately, the week-long workshop, held on the Beloit College campus 
in June 2005 and using the city of Beloit as a laboratory, resulted in the introduction of courses on Dakar in Transition and Quito in Transition, taught by local faculty in the respective cities. The Shanghai course was redesigned to become a Chinese Cities in Transition course, and a course on Moscow in Transition would subsequently be developed. As well, an anthropologist created a course on health and poverty with comparative work undertaken in Beloit and Nicaragua.

Critical to the curricular outcomes of Beloit College's faculty development activities has been a focus on how learning outside the classroom takes place, the particular challenges and opportunities for this learning in the cities where Beloit's partners are located, and interdisciplinary collaboration. As well, it has been important to realize that just as learning is developmental, with one stage of learning preparing for the next stage, so is curricular innovation. As faculty members experiment with new assignments, assessment of the assignments' effectiveness leads to changes in the assignments and the creation of new assignments. The faculty members' approach to teaching is similarly informed and affected by the interactions they have with other faculty members in curriculum development workshops and other kinds of faculty development. The developmental cycle for the Cities in Transition project, therefore, can be said to have begun with the initial identification of a problem. This was followed by activities - interdisciplinary faculty group visits to exchange partner sites - to better understand the context for students' study abroad.

The 2005 workshop in Beloit allowed participants to experiment with different kind of exercises, (mental mapping, walking, observing, taking photos) as well as read and discuss texts - scholarly, literary, journalistic - to give them concrete and abstract approaches to thinking about study abroad and the city. Texts participants read included two chapters from Rebecca Solnit's A Field Guide to Getting Lost (2005), selections from Orhan Pamuk's Istanbul: Memories of a City (2005), and an excerpt from Elaine Scarry's 2001 On Beauty and Being Just. Among others, the texts generated discussion about the degree to which we are willing and able to lose ourselves in order to be in a place (Solnit), the differences in how insiders and outsiders perceive, understand, and depict (or not) a city, its physical realities, residents, and history and culture (Pamuk), and our understanding of ourselves in relationship to others (Scarry). Essays on study abroad, such as those in Rockin' in Red Square: Critical Approaches to International Education in the Age of 
Cyberspace (W. Grünzweig and N. Rinehart, Eds., 2002) offered critiques of study abroad, while readings from cultural and urban geography provide theoretical frameworks for approaching the city. An implementation stage then took place, followed by assessment, curricular modifications, and additional curriculum development workshops, involving both those who had implemented Cities in Transition courses and other faculty now interested in investigating possibilities for their courses. Dissemination of the project through campus and off-campus presentations and publications has served not only to record the work, but push it forward in new directions.

What does a Cities in Transition course look like? Beloit College has now experimented with Cities in Transition courses in a number of locations, and the specific shape each course takes has been determined as much by the location of the course in a particular city or combination of city and other locales, as by the faculty instructors' knowledge and interests. At the core, however, are experiential learning assignments, reflection, and communication about the students' learning.

Nicaragua in Transition: Microcredit and Health thus draws on Paulo Freire's circle of praxis to use the develop students' ethnographic research skills usiing the city of Beloit as the object of study. Concurrently, the students learn about Nicaragua, microcredit, and health using readings from different disciplines. In a week spent in Nicaragua over Beloit College's spring break, the students and course instructor again follow Freire's model to explore the relationship between poverty, health, and micro-credit. The steps involved in Freire's model are "acquisition of new information and experiences, reflection and analysis; additional experience, information gathering, and reflection; and analysis and reflection, evaluation, and celebration (Krusko, N., 2010, p. 157)." Assignments in Beloit include using observation and photography to analyze the health of neighborhoods, gathering data on the food available in different grocery stores as a way to assess the availability of healthy food options, and a cultural bubble exercise requiring students to place themselves in a setting that is personally uncomfortable. In this latter assignment, the students keep a field journal to record objective observations, recording subjective responses to what they have seen in a separate journal where they also reflect on the implications of the exercise for their subsequent investigations in Nicaragua. Similar work is then undertaken in Nicaragua, where they visit local organizations working in the area of health and micro-credit and interview a variety of people connected 
to these. Upon return to Beloit from Nicaragua, the students' final project is to share what they have learned with the wider Beloit College community, requiring in turn that they unpack their experiences and the relationship of these to the theoretical and other texts they had read before traveling to Nicaragua. The students' first-hand observations of troubling phenomena such as poverty, the role of gender in determining who has access to resources, the effects of disease, violence, unemployment on children, give rise to emotions that are stronger than in the typical classroom, and teach students that affect plays a role in both what and how we see.

With the Nicaragua in Transition course, an instructor facilitates the students' learning both in Beloit and when the students are in Nicaragua. However, Cities in Transition courses for students studying abroad in Kaifeng and Jinan, China and Moscow, Russia take a very different shape, relying heavily on distance learning. Moscow in Transition and Chinese Cities in Transition share with Nicaragua in Transition the use of ethnographic research methods and experiential learning assignments. However, these courses place greater emphasis on writing, as it is primarily in writing that the students communicate with the course instructor and that they record and reflect on what they are learning. Greater independent study is also required, as at the heart of each course is a sustained, participant-observation project. Particularly in the case of China, the participant-observation project requires that the course instructor be comfortable working with students whose disciplinary interests may be very different from the instructor's. One project, for example, focused on the intersection of migration, religion, and ethnicity in Kaifeng, for which a student carried out her project in a small, family owned Halal restaurant. Another focused on the work of a Catholic hospice, while yet another focused on a park and the people who use it. A student interested in photography created a photo essay for his study of the interactions among vendors in Kaifeng's night markets. Daniel Youd, who has taught Chinese Cities in Transition several times, comments:

The collaborative approach to designing the Cities course has impacted the learning outcomes of the course in making it accessible to a broader range of students with interests often quite different from my own. Varied assignments and expectations have enabled more students to design and carry out successful Cities projects. (D. Youd, personal communication, July 30, 2010) 
A series of assignments prepare students to undertake their projects in China. In August, before the start of the local university's semester, the course instructor travels to China to work with the students for approximately ten days in Kaifeng. During this time, the students practice mapping skills, learn how to navigate the city and its different neighborhoods on foot as well as by using public transportation, and gain practice conducting interviews in China. Students are asked to map, navigate, and interview on their own, independent from each other and the instructor, so that they can gain the confidence to continue this kind of work when the instructor returns to the U.S., and so that they will be prepared to carry out projects of their own choosing. This confidence building is crucial, as even students with fairly strong Chinese language skills initially find it daunting to strike up conversations with strangers. One such student, for example, reported she was unsure of how to approach the driver of a motorized rickshaw she intended to interview about his work (Youd, 2010, p. 138); the ensuing conversation, however, moved beyond the questions she had prepared, allowing her to learn much more from the driver than she had anticipated. Fears of approaching strangers in Chinese began to disappear. This kind of initial confidence building has allowed even a student with just one year of Chinese prior to traveling to China to carry out an extended participant/observation project. In the process, the student enhanced his understanding of the topic he was studying, became closely connected to some of Kaifeng's residents, and greatly increased his facility with Chinese.

Course readings teach students to take ethnographic fieldnotes, and depending on the instructor, may include books relating other foreigners' experiences exploring China and using observations, interviews, objective analysis, and personal reflection to tell their stories (D. Youd, 2010, p. 148). By the time the instructor returns to China for a one-week stay with students in Jinan to do some comparative work and where one or more of the students may be spending the semester, the students need to have chosen a site for a month-long investigation of a particular aspect of China's urban transitions. The final written project that emerges from the investigation includes analysis and personal reflection and is underpinned with a record of interviews conducted, relevant vocabulary and secondary literature, and typically is illustrated with photos. Thus, the course helps students develop a number of life-long learning skills, among them how to enter and temporarily participate in the life of a foreign city in a respectful and responsible way and how to articulate the experience. 
Moscow in Transition has focused to a greater degree on one theme, commemoration and collective memory, as Moscow is "a city in perpetual dialogue with its past," as Donna Oliver (2009), the course instructor, has written. Oliver participated in a number of faculty development activities around Cities in Transition, among them the China seminar, 2005 and 2008 Cities in Transition seminars in Beloit, and a faculty seminar that she directed that focused on Moscow in Transition and concluded with a visit to that city in May 2006. Moscow in Transition involves just one week of on-site work with the instructor; this takes place in October during Beloit College's fall break. As in China, students are set a number of reading, exploratory, and writing assignments, and are expected to have settled on a project topic by the time the instructor arrives. Examples of projects for this course include the way in which house museums commemorate and convey history and what the Moscow subway can tell us about the past, Moscovites' relationship to it, and present-day Moscow. Student responses to the course show their engagement with the learning process as well as their consciousness of the roles they play in Moscow:

"I started out a tentative but enthused explorer .... I never felt like a real Muscovite.... Eventually, though, I felt like a real transplant, a genuine inhabitant confident in the ways and means of the city and able to accomplish whatever I might need to." (Shira Pittle)

"The more I walk through the city my mental map expands ... Every new place is an adventure. It makes me a little apprehensive, rather nervous. I hate to be unsure of where I going, to be out of control of a situation. I never realized how much I rely on staying within comfort zones until now. I am obviously forced every day to confront 'the other.' That thought seems expecially ironic considering I am the 'other' here." (Phillip Thomas)

"I missed walking in the city [as winter set in and I formed friendships], but I was also proud of the fact that I managed to [...] actually belong in a place on a daily basis" (Maryn Lewallen) (all quoted in D. Oliver, 2009).

As Donna Oliver states, the course will continue to evolve as she seeks to improve the learning outcomes for the students. But is not that the point? As we engage with the learning that takes place in study abroad, think about what we teach on the home campus related to it, and attempt interventions 
to help students learn abroad, is it not appropriate for our teaching to adapt to our changing knowledge and teaching skills, the students who come to us, and the conditions and opportunities on the ground?

\section{Outcomes and Next Steps}

The faculty development activities described here could not have been successful had they not been embedded in an larger project or process of changing the way Beloit College had thought about study abroad and its relationship to the curriculum, its mission, and the work of the faculty. Thus, the context in which the activities took place helped it reach Green and Olson's ever expanding "circle of engaged faculty." Including the participants in the 2005 workshop, 17 individuals have been involved directly in the Cities in Transition project, and another 18 in related faculty development activities around the integration of study abroad into the curriculum. These figures do not include additional Beloit College faculty members who attended a conference on integrating study abroad into the curriculum held at the college in November 2009 and/or who have participated in other study abroad initiatives.

For those who created Cities in Transition courses, the faculty development activities were of critical importance. Daniel Youd comments that faculty visits to China and Moscow "served as test runs for the course itself, as participants did course readings, carried out model assignments, and critiqued methodology and results [and] helped us imagine how students could frame their experiences [in the study abroad cities] using the skills they have acquired through their liberal arts training" (Youd, 2010, p. 151). Nancy Krusko notes that workshops held in Beloit allowed her "to gain new ideas for assignments, course units, and ways to make the link between overseas study and the course more apparent" (N. Krusko, personal communication, July 29, 2010). In fact, she incorporated mapping exercises into her Nicaragua in Transition course and developed the idea for going to markets to assess access to food in a workshop. Natalie Gummer, who has twice taught the Chinese Cities in Transition and now directs the College's first year seminar program, similarly notes that the workshops allowed her to "engage in the sorts of activities that we ask students to undertake.... This experience definitely enhanced my ability to design effective and interesting assignments" (N. Gummer, personal communication, July 30, 2010). These 
faculty members also report that an assessment of assignments undertaken at the beginning and end of the courses shows improvement in student learning in terms of understanding the cities in which they studied, the particular focus of courses (e.g. health in Beloit and Nicaragua, commemoration in Moscow) or the students' individual projects (e.g. migration in China), and themselves as young Americans.

A number of unexpected but welcome outcomes have also emerged from the Cities in Transition project and the faculty development activities that led to their creation and refinement. There are too many of them to relate here, but a few examples will provide a sense of the impact of the Cities in Transition project on faculty teaching and the curriculum:

One faculty member in Political Science hase experimented with using Skype and blogging to bring study abroad students into a political science course and will repeat this in a first year seminar in fall 2010. Not only will the study abroad students be encouraged to investigate particular topics as the play out in their host sites and relate these to the instructor and her first year students, but the first year students will begin to get an idea of what students can learn when they study abroad. Another faculty member in the same department has developed a number of experiential learning assignments for students that are carried out in the city of Beloit.

The director of Beloit College's Writing Program who is also a member of the English Department created a modular writing course for poststudy abroad students, and, inspired in part by a faculty development seminar on Istanbul in Transition, is considering alternative formats for courses to help Beloit students studying there on exchange engage with the city and prepare to connect it to their studies upon return. Meanwhile, in 2010/11 the English Department will investigate ways to better integrate study abroad into its curriculum.

Several first year seminar faculty members are in engaging in a pilot research project over the fall 2010 semester to assess the impact of community engaged learning on encouraging student agency. The Cities in Transition project is serving as the curricular model. The goal of the community engagement is to strengthen students' ownership of 
the learning process; it also will better prepare students for the kind of learning they will undertake should they study abroad.

A sociologist is creating a course that will look at families in transition in several of the cities in which Beloit College's exchange programs are located.

Faculty members in the Department of Modern Languages and Literatures are in the process of creating Cities in Transition modular courses for students who will study abroad in the Spanish-speaking world, with a 2-credit preparatory course in Beloit followed by a distance learning course in the next semester when the students abroad. A course is also to be developed for students studying abroad in Japan.

The very positive impacts of the Cities on Transition Project "at home" in Beloit do not mean no difficulties or challenges have been encountered. Faculty development activities require a great deal of organization and time commitments for those who engage in them. As well, while most participants find immediate application for their teaching, not all do, though virtually all find them useful for their advising, both because they better understand the study abroad experience, and because conversations with other faculty members have helped learn from each others' disciplinary perspectives. This is important their advisees take courses across the curriculum. As well, faculty development can be resource intensive. While undertaking faculty development activities on the home campus and in the city in which it is located requires little financial investment, group travel to the cities in which Beloit College students study has been invaluable to building faculty capacity and to developing new approaches to teaching, and this has required more substantial funding. Beloit College has been fortunate to receive grant and donor support the Cities in Transition project and related faculty development activities, but is mindful that grants run out, while the need for continued faculty development remains, in response to the changing composition of the faculty, new curricular directions, and so on. (Funding to send faculty to China and Russia for the on-site portion of those courses has been built into the study abroad budget.) Finally, teaching students remotely requires that students have the maturity to complete assignments on time; some students feel less accountable when the course instructor is not on site. Adding 
more structure to assignments and making expectations more explicit has helped in this area. Further, distance learning courses need to be accounted for within faculty teaching loads even if the students are not on campus, and this is not always easy at a small college.

The Beloit College experience, nevertheless, is that the city and study abroad have rich learning opportunities for both students and the faculty members who teach them, whether abroad or on the home campus, and that the lessons of the city and study abroad can also have wider implications for the home campus curriculum.

Note: The author is indebted to the many faculty members who have contributed to her understanding of the city and study abroad and who have brought creativity and intelligence to the Cities in Transition project specifically and to the integration of study abroad into the Beloit College curriculum more generally. Particular thanks are due to the faculty members mentioned in the above text.

\section{Ref e re nces}

American Council on Education (2008). Mapping internationalization on U.S. campuses: 2008 edition. Washington, DC: Author.

Beloit College. (2004). Proposal for a curriculum development workshop. Unpublished. Office of International Education files, Beloit College, Beloit, WI.

Beloit College. (2007-2008). Study abroad evaluation. Unpublished. Office of International Education files, Beloit College, Beloit, WI.

Beloit College (2009-2010). Study abroad evaluation. Unpublished. Office of International Education files, Beloit College, Beloit, WI.

Beloit College (2010). Study abroad evaluation analysis. Unpublished. Office of International Education files, Beloit College, Beloit, WI.

Bennett,J.M. (2008). On becoming a global soul: A path to engagement during study abroad. In V. Savicki (Ed.), Developing intercultural competence and transformation: Theory, research, and application in international education (pp. 13-31). Sterling, VA: Stylus.

Bok, D. (1986). Higher learning. Cambridge. MA: Harvard University.

Brewer, E. \& Cunningham, K. (Eds.), Integrating study abroad into the curriculum: Theory and practice across the disciplines. Sterling, VA: Stylus. 
Brewer, E. \& Solberg, J. (2010). Preparatory Courses for Students Going to Divergent Sites: Two Examples. In E. Brewer \& K. Cunningham (Eds.), Integrating study abroad into the curriculum: Theory and practice across the disciplines (pp. 41-62). Sterling, VA: Stylus.

Carlson, J. S., Burn, B. B. Useem, J., \& Yachimovicz, D. Study Abroad: The Experience of American Undergraduates. Westport, CT: Greenwood, 1990.

Deardorff, D. K. (2008). Intercultural competence: A definition, model, and implications for education abroad. In V. Savicki (Ed.), Developing intercultural competence and transformation: Theory, research, and application in international education (pp. 32-52). Sterling, VA: Stylus.

Edwards, J. (2000, Winter). The "Other Eden": Thoughts on American study abroad in Britain. Frontiers: The Interdisciplinary Journal of Study Abroad, 6, 83-98.

Green, M. F. and Olson, C. (2003). Internationalizing the campus: A user's guide. Washington, D.C.: American Council on Education, Center for Institutional and International Initiatives.

Grünzweig, W. and Rinehart, N. (Eds.) ( 2002). Rockin' in Red Square: Critical approaches to international education in the age of cyberspace. Münster: LIT.

Kelly, D. (2010 a.) Lessons from geography. In E. Brewer and K. Cunningham (Ed.), Integrating study abroad into the curriculum: Theory and practice across the disciplines (pp. 21-40). Sterling, VA: Stylus.

Kelly, D. (2010 b). Student learning in an international setting. In P. Eddy (Ed.) International collaborations: Opportunities, strategies, challenges (pp. 97-107). New Directions for Higher Education 150 (summer).

Krusko, N. (2010). Health and microcredit: Beloit as a laboratory for understanding Nicaragua." In E. Brewer and K. Cunningham (Ed.), Integrating study abroad into the curriculum: Theory and practice across the disciplines (pp. 155-171). Sterling, VA: Stylus.

Kulacki, G. (2000, Winter). Area studies and study abroad: The Chinese experience. Frontiers: The Interdisciplinary Journal of Study Abroad, 15, 23-46.

Lynch, K. (1960). The image of the city. Cambridge, MA: Massachusetts Institute of Technology. 
Oliver, D. (2009). Onion domes and skyscapers. Beloit College Magazine, Fall/Winter. Retrieved July 27, 2010 from http://www.beloit.edu/ belmag/belmag_wp/?p=650

Pamuk, O. (2005). Istanbul: Memories of a city. (M. Freely, Transl.) New York: Alfred A. Knopf.

Pusch, M.D. \& Merrill, M. (2008). Reflection, reciprocity, responsibility, and committed relativism: Intercultural development through international service-learning. In V. Savicki (Ed.), Developing intercultural competence and transformation: Theory, research, and application in international education (pp. 297-321). Sterling, VA: Stylus

Scarry, E. (2001). On beauty and being just. Princeton, NJ: Princeton University Press.

Selby, R. (2008). Designing transformation in international education. In V. Savicki (Ed.), Developing intercultural competence and transformation: Theory, research, and application in international education (pp. 1-10). Sterling, VA: Stylus.

Solnit, R. (2005). A field guide to getting lost. New York: Viking.

Sorcinelli, M. D. (2007). Faculty development: The challenge going forward. peerReview (Fall), 4-8. Retrieved July 29, 2010 from http://www.aacu. org/peerreview/pr-fa07/documents/PRFA07_FacDevl.pdf

Sorcinelli, M.D., Austin, A.E., Eddy, P.L., and Beach, A.L. (2006). Creating the future of faculty development: Learning from the past, understanding the present. San Francisco: Jossey-Bass.

Stohl, M. (2007). We have met the enemy and he is us: The role of the faculty in the internationalization of higher education in the coming decade. Journal of Studies in International Education, 11 (3/4) 359-372.

Vande Berg, M. (2007). Intervening in the learning of U.S. students abroad. Journal of Studies in International Education, 11 (3/4), 392-399.

Vande Berg, M. Paige, R.M., \& Connor-Linton, J. (2009). The Georgetown consortium project: Intervening in student learning abroad. Frontiers: The Interdisciplinary Journal of Education Abroad, XVIII (Fall), 1-75. 